\title{
Self-reported questionnaires for assessment adherence to treatment in patients with cardiovascular diseases
}

\author{
Corresponding author: \\ Agata Kosobucka, M.N.Sc \\ Department of Health Promotion \\ Collegium Medicum, \\ Nicolaus Copernicus University \\ Lukasiewicza St. 1, \\ 85-821 Bydgoszcz, Poland \\ e-mail: akosobucka@wp.p \\ tel: +4852 585-58-06
}

\begin{abstract}
Introduction: The treatment of acute coronary syndromes, besides coronary interventions, includes pharmacotherapy and lifestyle changes, which together determine a favourable prognosis. Adherence to treatment is a term describing a patient's behaviour in respect to the patient's maintenance of the health care provider's recommendations. Unfortunately, according to WHO data, adherence to long-term therapies for chronic illnesses in developed countries averages only $50 \%$.

Covered areas: Our study focused on available questionnaires for adherence assessment in everyday practice. A comprehensive search of data bases was conducted using appropriate keywords. Out of an initially identified 2081 citations, 93 articles were considered eligible for further analysis. Eventually, nine adherence scales were identified and reviewed.

Expert opinion: There is no so-called "gold standard survey" allowing accurate assessment of every patient for medication adherence. The use of a specific scale must be justified by its validation in a similar group of patients in well designed and properly conducted studies.

Keywords: adherence, assessment, coronary artery disease, questionnaire, scale, survey
\end{abstract}

Medical Research Journal 2017; Volume 2, Number 4, 115-122 . 5603/MRJ.2017.0015 Copyright (C) 2017 Via Medica ISSN 2451-2591

\section{Introduction}

Cardiovascular diseases are the main cause of death worldwide [1,2], and the number of adults with diagnosed chronic heart failure is increasing systematically [3]. In particular, the rate of acute coronary syndromes in developed countries remains high [4]. The treatment of acute coronary syndromes, as well as coronary interventions, includes pharmacotherapy and lifestyle changes, which together determine a favourable prognosis [5-7]. According to data available in the literature, only $8 \%$ of patients after myocardial infarction follow medical staff recommendations from their health care givers [8-12]. To systematise the phenomenon of following the medical recommendations, the term "adherence" is used. The World Health Organisation (WHO) defines "adherence" as "the extent to which a person's behaviour including taking medication, following a diet, and/or executing lifestyle changes, corresponds with agreed recommendations from a health care provider" [13]. According to Food and Drug Administration data, from 30 to $50 \%$ of patients do not strictly adhere to recommendations received from their healthcare providers, which significantly increases the risk of death [14-17]. The enhancement of adherence to medication is usually accompanied by elimination of unfavourable dietary habits and increased physical activity [18-22].

There are direct and indirect methods of adherence assessment; however, it seems impossible to point out one as clearly the best tool for measurement [23-26]. Observation of the treatment process and plasma concentrations of the medication or its metabolites, as well as biological markers, are proposed as direct methods allowing the assessment of adherence [27-30]. The indirect methods include: questionnaire surveys, analysis of pharmacy registers, the use of electronic devices measuring medication intake (e.g. containers registering time and frequency of taking medications), clinical observation of patients, and assessment of the progress of illness or its termination [25]. However, low reliability of patient self-reports with respect to adherence to health care recommendations as well as the potential costs of further verification of collected data are responsible for difficulties in the indirect assessment of adherence [31-33]. 
Table 1. Self-reported questionnaires for assessment adherence to treatment in patients with cardiovascular diseases

\begin{tabular}{llllll}
\hline No. & Questionnaire & $\begin{array}{l}\text { Year } \\
\text { of introduction }\end{array}$ & $\begin{array}{l}\text { Original } \\
\text { language }\end{array}$ & $\begin{array}{l}\text { Population in initial } \\
\text { validation study }\end{array}$ & $\begin{array}{l}\text { Internal } \\
\text { consistency } \\
\text { Cronbach's } \alpha\end{array}$ \\
\hline 1 & MMAS-4 & 1986 & English & Hypertension & 0.61 \\
2 & MMAS-8 & 2008 & English & Hypertension & 0.83 \\
3 & SEAMS & 2007 & English & $\begin{array}{l}\text { Coronary artery disease } \\
\text { with comorbidities }\end{array}$ & 0.89 \\
4 & HBCS & 2000 & English & Hypertension & 0.79 \\
5 & BMQ & $1999 / 2012$ & English/Portuguese & Hypertension & n.a./0.66 \\
6 & ACDS & 2016 & Polish & Coronary artery disease & 0.75 \\
& & & & with previous myocardial & infarction \\
7 & TAQPH & 2012 & Hypertension & 0.86 \\
8 & MBG & 2008 & Chinese & Hypertension & 0.89 \\
9 & ASRQ & 2008 & Spanish & Hypertension & n.a.
\end{tabular}

Morisky Medication Adherence Scale (MMAS); Self-efficacy for Appropriate Medication Use (SEAMS); Hill - Bone Compliance Scale (HBCS); Brief Medication Questionnaire (BMQ); Adherence in Chronic Diseases Scale (ACDS); Treatment Adherence Questionnaire for Patients with Hypertension (TAQPH); Martin-Bayarre-Grau questionnaire (MBG); Adherence Self-Report Questionnaire (ASRQ)

A systematic investigation of all published literature was conducted. We followed the PRISMA statement for reporting systematic reviews in health care interventions [34]. A database search including PubMed without time limitations was conducted by two independent investigators (AKo and KB). The following keywords were applied: "medication adherence assessment" or "questionnaire" or "survey" or "scale". References of retrieved studies were searched manually for additional studies and reviews. No language restrictions were applied. Data were abstracted on prespecified forms. All divergences were resolved by discussion with a third investigator (AKu). After a systematic search, 2081 citations were identified. Duplicate / multiple citations and reviews containing no relevant information were excluded. Eventually, 93 articles were considered eligible for further analysis, and nine adherence scales dedicated for patients with cardiovascular diseases were identified and reviewed (Table 1).

The aim of the study was to present available questionnaire-based methods of adherence assessment in patients with cardiovascular diseases.

\section{Morisky Medication Adherence Scales (MMAS-4 and MMAS-8)}

The most popular scale applied for the assessment of adherence is the MMAS. It is a quick and simple tool used by health care professionals [35]. The original Morisky scale published in 1986 has four items that have dichotomous response categories with yes or no [36]. The authors of this scale assumed that low adherence is mainly due to insufficient care, lack of accuracy, and forgetting. Moreover, patients modify doses of medica- tions according to their changeable well-being as well as their daily plans (e.g. leaving medications at home while traveling). The MMAS-4 was quite an innovative diagnostic tool at the time of its introduction due to its identification of the fundamental reasons for non-adherence to medication. However, it did not show optimal psychometric properties. The sensitivity and specificity were $81 \%$ and $44 \%$, respectively, with the Cronbach's alpha reliability of 0.61 , which is below the acceptable value of 0.7 . Despite fair psychometric characteristics, MMAS-4 is still in use [36].

The MMAS-4 differentiates whether the nonadherence is intentional or unintentional. The first two items refer to the unintentional non-adherence to treatment due to forgetfulness and carelessness. The last two items concern the intentional cessation of medication when feeling better or worse [37-38]

In 2008 the modified eight-item scale (MMAS-8) was developed to overcome the limitations of MMAS-4 [36]. The first seven items are dichotomous response categories with yes or no, and the last item inquires how often the responder misses the daily doses of medications, with five response options and corresponding different scoring. The MMAS-8 has much better psychometric properties with sensitivity and specificity of $93 \%$ and $53 \%$, respectively, and Cronbach's alpha value of 0.83. Moreover, the addition of four items allows us to identify and address the circumstances or situations related to adherence behaviour [36].

Validation of the scale was performed on a large number of patients with various chronic illnesses, including hypertension, hypercholesterolaemia, diabetes mellitus type 2, depression, Parkinson's disease, heart failure, coronary artery disease, and HIV [39-41]. 
The advantages of this scale are: the easiness of its application, widespread use in different diseases and populations, and concordance with pharmacy fill data or electronic monitoring devices. Furthermore, it is easy to understand and feasible to apply among different groups of patients, even during everyday visits. It works well for the assessment of the level of adherence to medications in patients suffering from hypertension or coronary artery disease [3,42-45]. However, it does not allow a comprehensive assessment of adherence behaviours because this scale does not provide adequate information regarding factors contributing to non-adherence to medication [42].

Thus, the Morisky scale can serve as a screening and monitoring tool to identify those patients with cardiovascular diseases who might have medication adherence problems, but the possibilities of developing interventions aimed at improving adherence on the basis of the results of this scale are limited [46-49]. This was supported by the observation by Sakthong et al. [47], who reported a lack of association of blood glucose concentration with Morisky scale score in diabetic patients.

\section{Self-efficacy for Appropriate Medication Use (SEAMS)}

The tool was created by Risser et al., who dealt with issues concerning health awareness. It is based on the social-cognitive theory of Bandura [50]. The authors assumed that patients' confidence in self effectiveness as well efforts aimed at achieving the desired result may improve adherence [50-51]. The psychometric characteristics were verified in a group of 436 patients with coronary artery disease and concomitant diseases such as diabetes, hypertension, and hypercholesterolaemia. The primary version of this scale consisted of 21 questions, but finally the number was limited. The final 13-item scale had good internal consistency reliability (Cronbach's alpha $=0.89$ ). A two-factor solution was found, explaining $52.3 \%$ of the scale's variance. The scale was recognised as a reliable and useful tool for the assessment of patient self-efficacy in chronic illness treatment. The SEAMS scale can be used successfully in patients having difficulties with reading and writing. This scale aims to identify barriers preventing a high level of adherence. Unfortunately, it is time-consuming, and this fact is considered to be its main disadvantage. This questionnaire evaluates three fundamental elements: patient self-efficacy for appropriate use of recommended medications, completeness of recommended pharmacotherapy, and lifestyle changes. The patient chooses one answer from three possibilities in a three-level Likert scale, where 1 means "I'm not sure", 2 "quite sure", and 3 "completely sure" $[39,50]$.

\section{Hill-Bone Compliance Scale (HBCS)}

This is a scale created for patients with hypertension. According to $\mathrm{WHO}$ data, over $50 \%$ of hypertensive patients do not take their medications in accordance with recommendations. It remains an important issue in many countries and explains why the Hill- Bone Compliance Scale was translated into numerous languages. The scale was created as a quick and simple tool allowing evaluation of adherence [33,52-53]. It indicates possible barriers to adherence and patient self-efficacy. This tool evaluates three significant elements of hypertension therapy. It is based on three subscales, each consisting of fourteen elements. They cover issues concerning the reduction of salt supply in daily diet, adherence to the scheduled visits, and medication-taking pattern. The answers describing the frequency of the elements mentioned above were incorporated from the Likert Scale and include answers as follows: "never", "sometimes", "mainly", and "all the time", with following additional options to choose from such as: "doesn't apply" and "I don't know". This scale was validated among hypertensive patients in South Africa, where this disease is very common but insufficiently diagnosed and often ignored by primary health care [52]. The authors compared results obtained from studies on black populations of urban areas covered by the primary health care system with results from patients hospitalised in internal medicine departments. The comparison was conducted among representatives of two ethnic groups, labelled in the study as "Black South Africans" and "African Americans". The validation procedure showed reasonable internal consistency (standardised Cronbach's alpha of 0.79 ), with an average inter-item correlation of 0.26 . In addition, the modified scale had significant predictive validity in that noncompliance predicted higher diastolic blood pressures $(p=0.21$, $p<05$ ) and medication noncompliance tended to predict higher systolic blood pressures ( $p=0.20, p<06)$. The researchers concluded that many behaviours strictly connected with hypertension treatment, such as application of medications, adherence to medical appointments, and reduction of salt supply in the diet, are similar in particular ethnic groups. They also confirmed that their scale may be successfully used in the daily clinical setting. Importantly, this tool requires identification and differentiation of non-adherent patients from non-responders to the applied treatment [52,54]. A study including 353 outpatients aimed to compare the psychometric characteristics of HBCS to the High Blood Pressure Therapy Scale versus Morisky Scale, and showed contradictory results of the scales in every third patient. For this reason, it is not recommended to use both tools at the same time [52]. The HBCS was also validated by other researchers from Turkey, after its adaptation to the Turkish primary care conditions [55]. 


\section{Brief Medication Questionnaire (BMQ)}

This tool is used for the assessment of adherence to medication. It also simultaneously indicates limitations related to the accomplishment of the therapeutic plan. The questionnaire was developed by Svarstad et al. [56]. The authors' intention was to create a short and sensitive tool for in-office identification of various causes of nonadherence in patients treated with angiotensin convertase inhibitors (enalapril or captopril). The form includes five questions concerning the prescribed pharmacotherapy. The first question verifies whether a patient brings his/her medications with him/her to the medical appointment. In the second question the patient is obliged to give the doses of the prescribed medications, and in the third question, by filling out a table, the patient is asked to write the names of the recommended drugs. Furthermore, the survey determines whether the patient has interrupted the therapy within the last six months. In the fifth, and last, question the patient is required to give the name of a medication that was not taken systematically and indicate the reason for its interruption. Although the questionnaire comprises only five questions, an appropriate combination of closed and open questions provides a broad picture of patient adherence. Properly selected questions allow us to evaluate patient knowledge of the recommended therapy and identify the obstacles in its observance. Using the $\mathrm{BMQ}$, the authors identified low adherence in $48.1 \%$ of patients [56]. The assessment of the patient's clinical profile alone (including the results of the laboratory tests, increased blood pressure, and self-assessment of the health state) was recognised as insufficient for identification of low adherence [56]. These observations led to further exploration of more objective methods of adherence assessment. The creation of the BMQ was a response to the need of hypertension therapy evaluation. This questionnaire was found to be useful for identification of patients who demand additional education, pharmaceutical support, or verification of the therapy plan [56]. This form, together with the Portuguese version of the Morisky-Green Test (MGT), was successfully used among patients with hypertension and diabetes in Southern Brazil [57]. The validation procedure was performed in 206 hypertensive patients attending primary healthcare. The tests showed good internal consistency by Cronbach's alpha $=0.66(95 \% \mathrm{Cl} 0.60$ to 0.73$)$. The BMQ had a sensitivity of $77 \%$, specificity of $58 \%$, and an area under the ROC curve of $0.70(95 \% \mathrm{Cl} 0.55$ to $0.86)$. The correlation between the $B M Q$ and the MGT was relatively low $r=0.28, p>0.001$.

Low adherence per the BMQ was associated with higher blood pressure levels when compared to adherent patients (148.4 [SD 20.1] vs. 128.8 [SD 17.8]; $p<0.001$ ), but not for the MGT. It was demonstrated that the $B M Q$ is significantly more effective among patients with uncontrolled hypertension [57]. The scale was also successfully used in patients with diabetes, depression, and other chronic illnesses [58-59].

\section{Adherence in Chronic Diseases Scale (ACDS)}

Recently Buszko et al. [60] published an article validating a new tool for adherence assessment. The ACDS questionnaire, created by A. Kubica, was designed to examine chronically ill adult patients. It allows the assessment of adherence itself, as well as identification of the most important factors influencing adherence, such as: acceptance of a therapy plan, cooperation between a patient and health care professionals, and the economic status of a patient [61-63]. The scale's validation was performed in a group of 413 patients with coronary artery disease [60]. Originally, the survey included eight questions with five possible answers. Four questions (No. 1, $3,4,5)$ concern the regularity of taking medications in prescribed doses, one question (No. 6) concerns acceptance of the provided therapy, while the last two questions (No. 7 and 8) refer to the patient-physician cooperation. The second question, referring to the assessment of the treatment-related financial burden, was finally removed due to insufficient cohesion with the other components of the questionnaire [60]. The result is a sum of all gained points.

In the original version of ACDS, possible scores ranged from 0 to 32 . Results below 24 points matched low adherence, while results of 24-28 points and above 29 points corresponded to medium and high adherence, respectively. The removal of the second question from the survey resulted in new centile distribution and reduced the spectrum of results to a range from 0 to 28 points. This time, results below 21 points, between 21-26 points, and above 26 points correspond, respectively, to low, medium, and high adherence. The internal consistency of the ACDS final version was assessed using Cronbach's alpha coefficient, and the value of 0.752 confirmed high reliability and homogeneity of the questionnaire [60].

The ACDS was subsequently applied in a single-centre, prospective, observational cohort clinical study with a six-month follow-up [64]. In a population of 221 patients with myocardial infarction treated with $\mathrm{PCl}$, lower scores for both of these ACDS items were associated with increased risk of acute coronary syndrome during follow-up (for item 2: $3.11 \pm 0.68$ vs. $3.45 \pm 0.73 ; p=0.02$, and for item 3 : $3.28 \pm 0.89$ vs. $3.64 \pm 0.64 ; p=0.04$ ), indicating predictive value of these items. A high level of adherence 
(ACDS score $>26$ points) was found in only $11.1 \%$ of patients who experienced acute coronary syndrome during follow-up versus $28.4 \%$ of subjects remaining free of this adverse event [64].

The scale is simple to use and may be applied in everyday medical practice and for research purposes [64-65]. The ability to assess the attitudes and behaviour of patients including the essential elements of the treatment process should be highlighted as strengths of this scale. [60]. The ASCD is available for free on the website of the Faculty of Health Science of the Nicolaus Copernicus University, Collegium Medicum (http://www.cm.umk. $\mathrm{pl} /$ wydzialy/wydzial-nauk-o-zdrowiu/jednostki-wydzialowe/katedra-i-zaklad-promocji-zdrowia.html).

\section{Treatment Adherence Questionnaire for Patients with Hypertension (TAQPH)}

Ma et al. [66] developed and tested the Treatment Adherence Questionnaire for Patients with Hypertension (TAQPH). The TAQPH consists of six subscales with 28 items. It is a measure dedicated for hypertensive patients allowing complete adherence evaluation including medication and lifestyle changes. The questionnaire was tested in a sample of 278 hypertensive patients in Guangdong Province of China, explaining $62.54 \%$ of the total variance in the data. Confirmative factor analysis supported a good overall fit of the six-factor model. The Cronbach's alpha coefficient of the overall questionnaire was 0.86 and 0.82 for test-retest reliability. The authors concluded that the TAQPH can be applied for research and clinical purposes [66].

\section{Martin-Bayarre-Grau Questionnaire (MBG)}

The Martin-Bayarre-Grau, a Spanish language 12item questionnaire, was validated in Cuba in a population of 114 hypertensive patients. The Cronbach's alpha coefficient of internal consistency was 0.889 for the sample [67]. The second validation was performed in 142 patients with hypertension, with a Cronbach's alpha value of 0.694 [68]. Validation results showed that the formulation of items was reasonable, clearly defined, and justified. The validation procedures allowed recognition of the existence of three factors: active adherence, autonomy in the face of treatment, and adherence complexity, all of which accounted for $68.7 \%$ and $63.4 \%$ of observed variance, respectively [67-68]. The favourable results of validation support the use of MBG in the field of research and medical practice.

\section{Adherence self-report questionnaire (ASRQ)}

Zeller et al. [69] evaluated a brief adherence self-report questionnaire (ASRQ) in 239 patients with hypertension using a medical event monitoring system, as the gold standard comparator. The main outcome measure was "timing adherence" (correct inter-dose intervals). Patients were asked to choose one of six descriptions (from level 1 = perfect adherence to level 6 = nonadherence) to express their medication taking at the end of the four-week study period. Most of the evaluated patients (89\%) stated perfect or nearly perfect adherence, and data from the electronic monitors showed a mean timing adherence of $88.3 \%(n=216)$. Using the cutoff of those who reported $A S R Q$ levels 1 and 2, a high percentage of those with comparatively high adherence according to MEMS were correctly identified (specificity, 90-93\%; negative predictive value, 66-96\%). However, sensitivity (detection of true non-adherers) and positive predictive value were poor to moderate $(14-42 \%$ and $22-66 \%$, respectively). According to these results the ASRQ was judged as a useful aid to facilitate the difficult differentiation between nonadherence and nonresponse to prescribed antihypertensive medication [69].

\section{Expert opinion}

Adherence to treatment and active participation of the patient in the therapeutic process not only is beneficial for particular individuals, but also carries economic benefits of a social dimension [70-72]. Considering that approximately half of the patients requiring treatment due to chronic disease do not adhere to the therapeutic plan, the assessment of patient adherence to treatment plays a pivotal role in the description and verification of the therapeutic process [43-44,73-75]. Thus, the search for available tools for adherence assessment as well as evaluation of their characteristics is necessary [76-78].

Several different scales evaluating adherence to treatment in patients with cardiovascular diseases have been developed. The Morisky Medication Adherence Scale (MMAS) is a short and easy survey identifying barriers to treatment adherence. So far, this is the most extensively studied scale, validated for a large number of diseases [35-49]. The Self-efficacy for Appropriate Medication Use (SEAMS) [50-51], the Hill-Bone Compliance Scale [52-55], the Brief Medication Questionnaire (BMQ) [56-59], the Treatment Adherence Questionnaire for Patients with Hypertension (TAQPH) [66], the Martin-Bayarre-Grau questionnaire (MBG) [67-68], and the Adherence Self-Report Questionnaire (ASRQ) [69] focus on patients with chronic cardiovascular diseases, 
mainly with hypertension. The Adherence in Chronic Diseases Scale (ACDS) is also designed for examining chronically ill, adult patients; however, it was validated and subsequently applied only in patients after myocardial infarction. It allows assessment of adherence itself, as well as identification of the most important factors influencing adherence, such as: acceptance of a therapy plan and cooperation between the patient and health care professionals [60-65].

The use of well-built questionnaires should allow effective identification of patients characterised by low adherence to treatment. Moreover, the knowledge of reasons of this phenomenon as well as identification of barriers and problems in cooperation between patients and health care professionals is crucial for implementation of tailored educational interventions [79-82].

There is no gold standard, nor a universal tool which could evaluate the level of adherence. Questionnaires may be used as a screening method to identify patients with a higher risk of low adherence. An advantage of questionnaires is the simplicity of the method and easiness of its application. However, selection of a tool with optimal characteristics for a particular population can be difficult [83-86]. Thus, a guide facilitating the choice of an appropriate scale is of great practical value. Each of the questionnaires is population-specific and was validated in separate populations of patients, precluding their deliberate application for adherence evaluation in other clinical settings than the originally validated ones [85-86]. The lack of a head-to-head comparison of questionnaires applicable for the same clinical setting, according to their characteristics, is a significant shortcoming, precluding indication of an optimal tool. In such situations the contents, complexity or simplicity, and additional information contained in the questionnaires should determine the choice of the most adequate scale for the purpose defined by the user.

Despite all weaknesses of the questionnaires applied for the assessment of adherence to treatment in large-scale studies and in clinical practice, the ease of use of this method and its low cost determines continuation of investigations aimed at improving the existing tools or development of new ones tailored for specific groups of patients [84,87]. There is an urgent need for prospectively conducted studies aimed at careful and standardised evaluation of the relevance, reliability, consistency, sensitivity, and specificity of the available scales in different clinical settings, to ensure identification of optimal research and a clinically applicable tool [88-90]. A medication adherence scale should be able to accurately capture the beliefs, barriers, and behaviours related to medication adherence [86,91]. Moreover, it should also be easy to apply. Significantly, clinicians or researchers should be cautious before using them as medication measurements and should consider two key points: 1) whether the adherence scale is appropriate for use in order to reach the goal of the study or an intervention; and 2) if the adherence scale is validated in this specific situation, which may be distinct from the original setting of validation [92-93].

\section{Conclusions}

Medication adherence scales are a subjective measure of medication adherence, used for studies conducted in different patient populations with various disease conditions. Many of the adherence scales are validated and compared against an objective measure of medication adherence. The use of a specific scale must be justified by its application and validation in a similar group of patients in well designed and properly conducted studies.

\section{References}

1. Santulli G. Epidemiology of cardiovascular disease in the 21th century: Updated numbers and updated facts. J Cardiovasc Dis July. 2013; 1: 1-2.

2. World Health Organization: Mortality and global burden of disease. www.who.int/gho/mortality burden disease/en/.

3. Zhao S, Zhao H, Wang $\mathrm{L}$, et al. Ēucation is critical for medication adherence in patients with coronary heart disease. Acta Cardiol. 2015; 70(2): 197-204, doi: 10.2143/AC.70.2.3073511, indexed in Pubmed: 26148380

4. Ortolani P, Solinas E, Guastaroba P, et al. Relevance of gender in patients with acute myocardial infarction undergoing coronary interventions. J Cardiovasc Med (Hagerstown). 2013; 14(6): 421-429, doi: 10.2459/JCM.0b013e328357bb04, indexed in Pubmed: 22914306.

5. Kubica A. Broszura - narzędzie edukacji zdrowotnej w kardiologii. Przyczynek do dyskusji o skuteczności profilaktyki wtórnej. Folia Cardiologica Excerpta. 2008; 3: 441.

6. Kubica A. Współpraca z pacjentem - podstawowy warunek skuteczności terapii w chorobie wieńcowej. Choroby Serca i Naczyń. 2009; 6: 131.

7. Kubica A. Psychologiczny aspekt zawału serca - niedoceniana zmienna w procesie terapii i rehabilitacji. Folia Cardiologica Excerpta. 2009; 4: 197.

8. Albert NM. Improving medication adherence in chronic cardiovascular disease. Crit Care Nurse. 2008; 28(5): 54-64; quiz 65, indexed in Pubmed: 18827087.

9. Choudhry NK, Patrick AR, Antman EM, et al. Cost-effectiveness of providing full drug coverage to increase medication adherence in post-myocardial infarction Medicare beneficiaries. Circulation. 2008; 117(10): 1261-1268, doi: 10.1161/CIRCULATIONAHA.107.735605, indexed in Pubmed: 18285564

10. Polack J, Jorgenson D, Robertson P. Evaluation of different methods of providing medication-related education to patients following myocardial infarction. Can J Hosp Pharm. 2008; 141(4): 241-247.

11. Kubica A, Pufal J, Moczulska B, et al. Ocena wiedzy dotyczącej profilaktyki i objawów choroby niedokrwiennej serca u osób hospitalizowanych w klinice kardiologii. Psychiatria w Praktyce Ogólnolekarskiej. 2004; 4: 135.

12. Kubica A, Pufal J, Moczulska B, et al. Skuteczność edukacji zdrowotnej u osób hospitalizowanych w klinice kardiologii. Psychiatria w Praktyce Ogólnolekarskiej. 2005; 5: 61.

13. Geest SDe, Sabaté E. Adherence to Long-Term Therapies: Evidence for Action. European Journal of Cardiovascular Nursing. 2016; 2(4): 323-323, doi: 10.1016/s1474-5151(03)00091-4

14. Simpson SH, Eurich DT, Majumdar SR, et al. A meta-analysis of the association between adherence to drug therapy and mortality. BMJ. 2006; 333(7557): 15, doi: 10.1136/bmj.38875.675486.55, indexed in Pubmed: 16790458.

15. Kubica J, Adamski P, Buszko K, et al. Rationale and Design of the Effectiveness of LowEr maintenanCe dose of TicagRelor early After my- 
ocardial infarction (ELECTRA) pilot study. Eur Heart J Cardiovasc Pharmacother. 2017 [Epub ahead of print], doi: 10.1093/ehjcvp/pvx032, indexed in Pubmed: 29040445.

16. Winter MP, Grove EL, De Caterina R, et al. Advocating cardiovascular precision medicine with $\mathrm{P} 2 \mathrm{Y} 12$ receptor inhibitors. Eur Heart J Cardiovasc Pharmacother. 2017; 3(4): 221-234, doi: 10.1093/ehjcvp/pvw044, indexed in Pubmed: 28204303.

17. Winter MP, Koziński M, Kubica J, et al. Personalized antiplatelet therapy with P2Y12 receptor inhibitors: benefits and pitfalls. Postepy Kardiol Interwencyjnej. 2015; 11(4): 259-280, doi: 10.5114/pwki.2015.55596, indexed in Pubmed: 26677375.

18. Stewart K, Mc Namara KP, George J. Challenges in measuring medication adherence: experiences from a controlled trial. Int J Clin Pharm. 2014; 36(1): 15-19, doi: 10.1007/s11096-013-9877-6, indexed in Pubmed: 24293282.

19. Kubica A, Sinkiewicz W, Szymański P, et al. Edukacja zdrowotna w chorobach układu krążenia - możliwości i zagrożenia. Folia Cardiologica Excerpta. 2007; 2: 177

20. Kubica A. Wybrane problemy prewencji wtórnej u chorych po incydentach wieńcowych. Folia Cardiologica Excerpta. 2008; 3: 366.

21. Kubica A, Obońska K, Kasprzak M, et al. The impact of metabolic syndrome on the antiplatelet effect of clopidogrel and aspirin in patients with acute coronary syndrome. : Folia Med Copernicana. 2014; 2: 66-72.

22. Kubica A, Kasprzak M, Obońska K, et al. Impact of health education on adherence to clopidogrel and clinical effectiveness of antiplatelet treatment in patients after myocardial infarction. Medical Research Journal. 2016; 3(4): 154-159, doi: 10.5603/fmc.2015.0010.

23. Li WW, Kuo CT, Hwang SL, et al. Factors related to medication non-adherence for patients with hypertension in Taiwan. J Clin Nurs. 2012 21(13-14): 1816-1824, doi: 10.1111/j.1365-2702.2012.04088.x, indexed in Pubmed: 22672451.

24. Jeffery RA, Navarro T, Wilczynski NL, et al. Adherence measurement and patient recruitment methods are poor in intervention trials to improve patient adherence. J Clin Epidemiol. 2014; 67(10): 1076-1082, doi: 10.1016/j.jclinepi.2014.06.008, indexed in Pubmed: 25087180.

25. Osterberg L, Blaschke T. Adherence to medication. N Engl J Med. 2005; 353(5): 487-497, doi: 10.1056/NEJMra050100, indexed in Pubmed: 16079372.

26. Jimmy B, Jose J. Patient medication adherence: measures in daily practice. Oman Med J. 2011; 26(3): 155-159, doi: 10.5001/omj.2011.38, indexed in Pubmed: 22043406.

27. Kubica A. Problems of long-term antiplatelet therapy after coronary stent implantation. Advances in Interventional Cardiology. 2009; 5: 158-161.

28. Kubica A, Obońska K, Kasprzak M, et al. The impact of metabolic syndrome on the antiplatelet effect of clopidogrel and aspirin in patients with acute coronary syndrome. Folia Med Copernicana. 2014; 2: 66-72.

29. Kubica A, Kozinski M, Grzesk G, et al. Genetic determinants of platelet response to clopidogrel. J Thromb Thrombolysis. 2011: 32(4): 459466, doi: 10.1007/s11239-011-0611-8, indexed in Pubmed: 21706290.

30. Adamski P, Sikora J, Laskowska E, et al. Comparison of bioavailability and antiplatelet action of ticagrelor in patients with ST-elevation myocardial infarction and non-ST-elevation myocardial infarction: A prospective, observational, single-centre study. PLoS One. 2017 12(10): e0186013, doi: 10.1371/journal.pone.0186013, indexed in Pubmed: 29023473.

31. Vrijens B, De Geest S, Hughes DA, et al. ABC Project Team A new taxonomy for describing and defining adherence to medications. Br J Clin Pharmacol. 2012; 73(5): 691-705, doi: 10.1111/j.1365-2125.2012.04167.x, indexed in Pubmed: 22486599.

32. Lam WY, Fresco P. Medication Adherence Measures: An Overview. Biomed Res Int. 2015; 2015: 217047, doi: 10.1155/2015/217047, indexed in Pubmed: 26539470.

33. Kubica A, Grześk G, Sinkiewicz W, et al. Compliance, concordance, adherence in chronic therapy. Folia Cardiol Excerpta. 2010; 5: 54-57.

34. Moher D, Liberati A, Tetzlaff J, et al. PRISMA Group. Preferred reporting items for systematic reviews and meta-analyses: the PRISMA Statement. Open Med. 2009; 3(3): e123-e130, indexed in Pubmed: 21603045

35. Cuevas CD, Peñate W. Psychometric properties of the eight-item Morisky Medication Adherence Scale (MMAS-8) in a psychiatric outpatient setting. International Journal of Clinical and Health Psychology. 2015; 15(2): 121-129, doi: 10.1016/j.ijchp.2014.11.003.

36. Morisky DE, Green LW, Levine DM. Concurrent and predictive validity of a self-reported measure of medication adherence. Med Care. 1986; 24(1): 67-74, indexed in Pubmed: 3945130.

37. Muntner $P$, Joyce $C$, Holt E, et al. Defining the minimal detectable change in scores on the eight-item Morisky Medication Adherence Scale.
Ann Pharmacother. 2011; 45(5): 569-575, doi: 10.1345/aph.1P677. indexed in Pubmed: 21521862.

38. Tan Xi, Patel I, Chang J. Review of the four item Morisky Medication Adherence Scale (MMAS-4) and eight item Morisky Medication Adherence Scale (MMAS-8). INNOVATIONS in pharmacy. 2014; 5(3), doi: 10.24926/iip.v5i3.347.

39. Lavsa SM, Holzworth A, Ansani NT. Selection of a validated scale for measuring medication adherence. J Am Pharm Assoc (2003). 2011; 51(1): 90-94, doi: 10.1331/JAPhA.2011.09154, indexed in Pubmed: 21247831.

40. Afonso N, Nassif G, Aranba A et al. Low-density lipoprotein cholesterol goal attainment among high- risk patient: does a combine intervention targeting patients and provides work? AM J Mang Care. 2006; 12(10): 589

41. George CF, Peveler RC, Heiliger S, et al. Compliance with tricyclic antidepressants: the value of four different methods of assessment. $\mathrm{Br} \mathrm{J}$ Clin Pharmacol. 2000; 50(2): 166-171, indexed in Pubmed: 10930969.

42. Pandey A, Raza F, Velasco A, et al. Comparison of Morisky Medication Adherence Scale with therapeutic drug monitoring in apparent treatment-resistant hypertension. J Am Soc Hypertens. 2015; 9(6): 420-426. e2, doi: 10.1016/j.jash.2015.04.004, indexed in Pubmed: 26051923.

43. Marcum ZA, Zheng Y, Perera S, et al. Health ABC Study. Prevalence and correlates of self-reported medication non-adherence among older adults with coronary heart disease, diabetes mellitus, and/or hypertension. Res Social Adm Pharm. 2013; 9(6): 817-827, doi: 10.1016/j. sapharm.2012.12.002, indexed in Pubmed: 23291338.

44. Kripalani S, Schmotzer B, Jacobson TA. Improving Medication Adherence through Graphically Enhanced Interventions in Coronary Heart Disease (IMAGE-CHD): a randomized controlled trial. J Gen Intern Med. 2012; 27(12): 1609-1617, doi: 10.1007/s11606-012-2136-z, indexed in Pubmed: 22790614

45. Korb-Savoldelli V, Gillaizeau F, Pouchot J, et al. Validation of a French version of the 8-item Morisky medication adherence scale in hypertensive adults. J Clin Hypertens (Greenwich). 2012; 14(7): 429-434, doi: 10.1111/j.1751-7176.2012.00634.x, indexed in Pubmed: 22747615.

46. Unni EJ, Farris KB. Development of a new scale to measure self-reported medication nonadherence. Res Social Adm Pharm. 2015; 11(3): e133-e143, doi: 10.1016/j.sapharm.2009.06.005, indexed in Pubmed: 21272524.

47. Sakthong $P$, Chabunthom R, Charoenvisuthiwongs R. Psychometric properties of the Thai version of the 8-item Morisky Medication Adherence Scale in patients with type 2 diabetes. Ann Pharmacother 2009; 43(5): 950-957, doi: 10.1345/aph.1L453, indexed in Pubmed: 19366872 .

48. Morisky DE, Ang A, Krousel-Wood M, et al. Predictive validity of a medication adherence measure in an outpatient setting. J Clin Hypertens (Greenwich). 2008; 10(5): 348-354, indexed in Pubmed: 18453793.

49. Saleem F, Hassali MA, Shafie AA, et al. Translation and validation study of Morisky Medication Adherence Scale (MMAS): the Urdu version for facilitating person-centered healthcare in Pakistan. Int J Pers Cent Med. 2012; 2: 384-390.

50. Risser J, Jacobson TA, Kripalani S. Development and psychometric evaluation of the Self-efficacy for Appropriate Medication Use Scale (SEAMS) in low-literacy patients with chronic disease. J Nurs Meas. 2007; 15(3): 203-219, indexed in Pubmed: 18232619.

51. Rapin P, Yupin A, Sureeporn T, et al. Validity and Reliability of Thai Version of Questionnaire Measuring Self-efficacy for Appropriate Medication Use Scale among Thai with post-myocardial infarction. Songklanakarin J Sci Technol. 2014; 36: 411-417.

52. Lambert EV Steyn K Stender $S$, et al. Cross-cultural validation of the hill-bone compliance to high blood pressure therapy scale in a South African, primary healthcare setting. Ethn Dis. 2006; 16(1): 286-291, indexed in Pubmed: 16599385

53. Kim MT, Hill MN, Bone LR, et al. Development and testing of the Hill-Bone Compliance to High Blood Pressure Therapy Scale. Prog Cardiovasc Nurs. 2000; 15(3): 90-96, indexed in Pubmed: 10951950.

54. Song Y, Han HR, Song HJ, et al. Psychometric evaluation of hill-bone medication adherence subscale. Asian Nurs Res (Korean Soc Nurs Sci). 2011; 5(3): 183-188, doi: 10.1016/j.anr.2011.09.007, indexed in Pubmed: 25030368

55. Karademir M, Koseoglu IH, Vatansever K, et al. Validity and reliability of the Turkish version of the Hill-Bone compliance to high blood pressure therapy scale for use in primary health care settings. Eur J Gen Pract. 2009; 15(4): 207-211, doi: 10.3109/13814780903452150, indexed in Pubmed: 20055720

56. Svarstad BL, Chewning BA, Sleath BL, et al. The Brief Medication Questionnaire: a tool for screening patient adherence and barriers to adherence. Patient Educ Couns. 1999; 37(2): 113-124, indexed in Pubmed: 14528539 
57. Ben AJ, Neumann CR, Mengue SS. The Brief Medication Questionnaire and Morisky-Green test to evaluate medication adherence. Rev Saude Publica. 2012; 46(2): 279-289, indexed in Pubmed: 22331180

58. Krass I, Taylor SJ, Smith C, et al. Impact on medication use and adherence of Australian pharmacists' diabetes care services. J Am Pharm Assoc (2003). 2005; 45(1): 33-40, indexed in Pubmed: 15730115

59. Rickles NM, Svarstad BL. Relationships between multiple self-reported nonadherence measures and pharmacy records. Res Social Adm Pharm. 2007; 3(4): 363-377, doi: 10.1016/j.sapharm.2006.11.001, indexed in Pubmed: 18082873.

60. Buszko K, Obońska K, Michalski P et al. The Adherence Scale in Chronic Diseases (ASCD). The power of knowledge: the key to successfu patient - health care provider cooperation. Medical Research Journal. 2016; 1(1): 37-42, doi: 10.5603/mri.2016.0006.

61. Lucca JM, Ramesh M, Parthasarathi G, et al. Incidence and factors associated with medication nonadherence in patients with mental illness: a cross-sectional study. J Postgrad Med. 2015; 61(4): 251-256, doi: 10.4103/0022-3859.166514, indexed in Pubmed: 26440396

62. Kane S, Shaya F. Medication non-adherence is associated with increased medical health care costs. Dig Dis Sci. 2008; 53(4): 1020-1024 doi: 10.1007/s10620-007-9968-0, indexed in Pubmed: 17934828.

63. Haynes RB, Yao X, Degani A, et al. Interventions for enhancing medication adherence. Cochrane Database of Systematic Reviews. 2005 doi: 10.1002/14651858.cd000011.pub2.

64. Kosobucka A, Michalski P, Pietrzykowski $\measuredangle$, et al. Adherence to treatment assessed with the Adherence in Chronic Diseases Scale in patients after myocardial infarction. Patient Preference and Adherence. 2018; Volume 12: 333-340, doi: 10.2147/ppa.s150435.

65. Kubica A, Kosobucka A, Michalski P, et al. The Adherence in Chronic Diseases Scale - a new tool to monitor implementation of a treatment plan. Folia Cardiologica 2017:12:19-26, DOI: 10. 5603/FC. ; 2016 0000, doi: 10.5603/FC.2016.0000

66. Ma C, Chen S, You L, et al. Development and psychometric evaluation of the Treatment Adherence Questionnaire for Patients with Hypertension. J Adv Nurs. 2012; 68(6): 1402-1413, doi: 10.1111/j.1365 -2648.2011.05835.x, indexed in Pubmed: 21954893.

67. Martin AL, Bayarre Ve. Grau Ábalo JA Validation of MBG Questionnaire (Martin-Bayarre-Grau) for the evaluation of therapy adherence in blood hypertension patients. Rev Cuba Salud Publica. ; 2008: 34

68. Martínez JW Villa Pe, Jaramillo J Quintero Betancur AM, Calderón V. Validación del cuestionario de adherencia al tratamiento anti hipertensivo Martín Bayarré Grau. [Validation of a scale of adherence treatment antihypertensive: Martin Bayarre Grau Test]. Rev Med Risaralda. 2011 17: 101-105.

69. Zeller A, Schroeder K, Peters TJ. An adherence self-report questionnaire facilitated the differentiation between nonadherence and nonresponse to antihypertensive treatment. J Clin Epidemiol. 2008; 61(3): 282-288, doi: 10.1016/j.jclinepi.2007.04.007, indexed in Pubmed: 18226752.

70. Kubica A, Jurek A, Olejarczyk E, et al. Wybrane czynniki demograficzno-społeczne a skuteczność edukacji zdrowotnej prowadzone na podstawie broszur edukacyjnych u osób z ostrym zawałem serca. Folia Cardiologica Excerpta. 2008; 3: 199.

71. Kubica A, Kochman W, Bogdan M, et al. The influence of undergone percutaneous coronary interventions, and earlier hospitalizations with myocardial infarction on the level of knowledge and the effectiveness of health education in patients with myocardial infarction. Advances in Interventional Cardiology. 2009; 5: 25-30.

72. DiMatteo MR. Variations in patients' adherence to medical recommendations: a quantitative review of 50 years of research. Med Care. 2004 42(3): 200-209, indexed in Pubmed: 15076819.

73. Tang L, Patao C, Chuang J, et al. Cardiovascular risk factor control and adherence to recommended lifestyle and medical therapies in persons with coronary heart disease (from the National Health and Nutrition Examination Survey 2007-2010). Am J Cardiol. 2013; 112(8): 1126-1132, doi: 10.1016/j.amjcard.2013.05.064, indexed in Pubmed: 23827404

74. Galema-Boers JMH, Lenzen MJ, van Domburg RT, et al. Predicting non-adherence in patients with familial hypercholesterolemia. Eur J Clin Pharmacol. 2014; 70(4): 391-397, doi: 10.1007/s00228-013-1640-3, indexed in Pubmed: 24449092

75. Spertus JA, Kettelkamp R, Vance C, et al. Prevalence, predictors and outcomes of premature discontinuation of thienopyridine therapy after drug-eluting stent placement: results from the PREMIER registry. Circulation. 2006; 113(24): 2803-2809, doi: 10.1161/CIRCULATIONAHA.106.618066, indexed in Pubmed: 16769908.

76. Kubica A, Kasprzak M, Obońska K, et al. Discrepancies in assessment of adherence to antiplatelet treatment after myocardial infarction. Pharmacology. 2015; 95(1-2): 50-58, doi: 10.1159/000371392, indexed in Pubmed: 25592409

77. Kubica A Obońska K, Fabiszak T, et al. Adherence to antiplatelet treatment with P2Y12 receptor inhibitors. Is there anything we can do to improve it? A systematic review of randomized trials. Curr Med Res Opin. 2016: 32(8): 1441-1451, doi: 10.1080/03007995.2016.1182901, indexed in Pubmed: 27112628

78. Kubica A, Kasprzak M, Siller-Matula J, et al. Time-related changes in determinants of antiplatelet effect of clopidogrel in patients after myocardial infarction. Eur J Pharmacol. 2014; 742: 47-54, doi: 10.1016/j. ejphar.2014.08.009, indexed in Pubmed: 25199965.

79. Muntner P, Mann DM, Woodward M, et al. Predictors of low clopidogrel adherence following percutaneous coronary intervention. Am J Cardiol. 2011; 108(6): 822-827, doi: 10.1016/j.amjcard.2011.04.034, indexed in Pubmed: 21741610

80. Kubica A, Obońska K, Kasprzak M, et al. Prediction of high risk of non-adherence to antiplatelet treatment. Kardiol Pol. 2016; 74(1): 61-67, doi: 10.5603/KP.a2015.0117, indexed in Pubmed: 26101025.

81. Vitolins MZ, Rand CS, Rapp SR, et al. Measuring adherence to behavioral and medical interventions. Control Clin Trials. 2000; 21 (5 Suppl): 188S-94S, indexed in Pubmed: 11018574.

82. Garber MC, Nau DP Erickson SR et al. The concordance of self-report with other measures of medication adherence: a summary of the literature. Med Care. 2004; 42(7): 649-652, indexed in Pubmed: 15213489.

83. Cook CL, Wade WE, Martin BC, et al. Concordance among three self-reported measures of medication adherence and pharmacy refill records. J Am Pharm Assoc (2003). 2005; 45(2): 151-159, indexed in Pubmed: 15868757.

84. Wang PS, Benner JS, Glynn RJ, et al. How well do patients report noncompliance with antihypertensive medications?: a comparison of self-report versus filled prescriptions. Pharmacoepidemiol Drug Saf. 2004; 13(1): 11-19, doi: 10.1002/pds.819, indexed in Pubmed: 14971118.

85. Frost MH, Reeve BB, Liepa AM, et al. Mayo/FDA Patient-Reported Outcomes Consensus Meeting Group;. What is sufficient evidence for the reliability and validity of patient-reported outcome measures? Value Health. 2007; 10 Suppl 2: S94-S9S105, doi: 10.1111/j.1524-4733.2007.00272.x, indexed in Pubmed: 17995479.

86. Krousel-Wood M, Muntner P, Jannu A, et al. Reliability of a medication adherence measure in an outpatient setting. Am J Med Sci. 2005; 330(3): 128-133, indexed in Pubmed: 16174996

87. Kubica A. Collaboration with the patient - a basic condition of therapy effectiveness in coronary artery disease. Chor. Serca Nacz. 2009; 6: 131-134.

88. Farmer $\mathrm{KC}$. Methods for measuring and monitoring medication regimen adherence in clinical trials and clinical practice. Clin Ther. 1999; 21(6): 1074-90; discussion 1073, doi: 10.1016/S0149-2918(99)800265, indexed in Pubmed: 10440628

89. $\mathrm{Ho}$ PM Bryson CL, Rumsfeld JS. Medication adherence: its importance in cardiovascular outcomes. Circulation. 2009; 119(23): 3028-3035, doi: 10.1161/CIRCULATIONAHA.108.768986, indexed in Pubmed: 19528344.

90. Ho PM, Spertus JA, Masoudi FA, et al. Impact of medication therapy discontinuation on mortality after myocardial infarction. Arch Intern Med. 2006; 166(17): 1842-1847, doi: 10.1001/archinte.166.17.1842, indexed in Pubmed: 17000940.

91. Vermeire E, Hearnshaw $H$, Van Royen $P$, et al. Patient adherence to treatment: three decades of research. A comprehensive review. J Clin Pharm Ther. 2001: 26(5): 331-342, indexed in Pubmed: 11679023.

92. Shi L, Liu J, Fonseca V, et al. Correlation between adherence rates measured by MEMS and self-reported questionnaires: a meta-analysis. Health Qual Life Outcomes. 2010; 8: 99, doi: 10.1186/1477-75258-99, indexed in Pubmed: 20836888.

93. Pérez-Escamilla B, Franco-Trigo L, Moullin JC, et al. Identification of validated questionnaires to measure adherence to pharmacological antihypertensive treatments. Patient Prefer Adherence. 2015; 9: 569-578, doi: 10.2147/PPA.S76139, indexed in Pubmed: 25926723. 